\title{
PEMBUATAN PUPUK ORGANIK CAIR DARI AIR REBUSAN OLAHAN KEDELAI MENGGUNAKAN EFFECTIVE MIKROORGANISME
}

\author{
Suwardiyono $^{1}$, Farikha Maharani ${ }^{1}$ dan Harianingsih ${ }^{2 *}$ \\ ${ }^{1}$ Jurusan Teknik Kimia, Fakultas Teknik, Universitas Wahid Hasyim \\ Jl. Menoreh Tengah X/22 Sampangan, Semarang \\ ${ }^{2}$ Jurusan Teknik Kimia, Fakultas Teknik, Universitas Negeri Semarang \\ Kampus Sekaran, Gunungpati, Semarang \\ *Email : harianingsih@mail.unnes.ac.id
}

\begin{abstract}
Abstrak
Penelitian pembuatan pupuk organik cair dari air rebusan olahan kedelai dengan penambahan effevtive mikroorganisme (EM4) sebagai bioaktivator bertujuan untuk menentukan pengaruh waktu fermentasi terhadap kandungan Nitrogen $(N)$ dan Fospor $(P)$ dalam pupuk organik cair. Metode pembuatan pupuk organic cair inimerupakan proses fermentasi $500 \mathrm{ml}$ air rebusan kedelai dalam bak fermentor dengan penambahan EM4 sebanyak $15 \mathrm{ml}$ dan sukrosa dan variasi waktu fermentasi 4,6,8,10,12,14 hari. Variasi pengambilan sampel berikutnya dilakukan dengan penambahan EM4 sebanyak 5,10,15, $20 \mathrm{ml}$ dan waktu fermentasi 14 hari. Parameter yang diuji adalah prosentase nitrogen dan Fosfor menggunakan uji Kjeldah dan dilanjutkan dengan uji kandungan Fosfor menggunakan spektrofotometer pada panjang gelombang 650-750nm. Hasil dari penelitian ini dengan penambahan $15 \mathrm{ml}$ EM4 diperoleh prosentase nitrogen dan phosphor pada hari ke-10 sebesar $0,302 \%$ dan 0,0068\%. Semakin lama waktu fermentasi maka prosentase semakin turun antara lain pada waktu 14 hari kandungan nitrogen dan phosphor yang diperoleh 0,128\% dan $0,0014 \%$.
\end{abstract}

Kata kunci : Air rebusan Kedelai, Effective Microorganisme, Pupuk Organik Cair

\section{PENDAHULUAN}

Pada penelitian ini digunakan air rebusan hasil olahan kedelai yang dihasilkan oleh Kampung Olahan Kedelai Sumurejo Gunungpati Semarang. Olahan kedelai pada Kampung tematik ini berupa tahu, tempe, nugget kedelai, keripik dan olahan lainnya. Volume air rebusan yang dihasilkan pada produksi olahan kedelai mencapai 1 ton setiap harinya dan akhirnya hanya disimpan sampai waktu yang tepat untuk membuang ke sungai atau digunakan untuk menyiram tanaman di sekitarnya. Akan tetapi volume air rebusan hasil olahan kedelai yang melimpah membuat para produsen membuang ke sungai.

Air rebusan olahan kedelai mengandung $0,11 \%$ karbohidrat, $0,42 \%$ protein, $0,13 \%$ lemak, 4,55\% besi, 1,74\% fosfor dan 98,8\% air (Yuliarti, 2009). Sehingga perlu adanya pengolahan dan pemanfaatan limbah cair hasil rebusan olahan kedelai sebagai bahan olahan yang bermanfaat. Dari latar belakang tersebut, penelitian ini ingin memanfaaatkan air rebusan hasil olahan kedelai menjadi pupuk organik cair. Dimana kebutuhan pupuk di Semarang masih sangat tinggi.

Sehingga harapannya dengan pembuatan pupuk organic cair ini selain sebagai solusi agar air rebusan olahan kedelai lebih mempunyai nilai manfaat juga untuk memenuhi kebutuhan petani di Semarang dan sekitarnya untuk pemenuhan kebutuhan pupuk. Pupuk organik cair adalah pupuk terbuat dari sisa-sisa makhluk hidup yang diolah melalui proses pembusukan (dekomposisi) oleh bakteri pengurai (Utomo, 2007). Pupuk organic cair merupakan pupuk yang terbuat dari bahan Pupuk organic organic yang berasal dari tanaman atau kotoran hewan dengan rekayasa proses untuk memperbaiki yansifat fisika kimia dan biologi (Mulyaningsih, Sunarto, \& Prasetya, 2013).

Pupuk organik adalah hasil akhir proses penguraian bagian-bagian atau sisa tanaman dan binatang contohnya pupuk kompos dan pupuk kandang (Yuliarti, 2009). Pupuk kompos berasal dari sisa-sisa tanaman dan pupuk kandang berasal dari kotoran ternak. Pupuk organik dapat meningkatkan anion-anion yang penting untuk pertumbuhan tanaman antara lain: nitrat, fosfat, sulfat, borat, dan klorida (Yunizardi, 2017). Pada penelitian pembuatan pupuk organic dari air rebusan kedelai akan dianalisis kandungan nitrogen dan fosfor.

Nitrogen merupakan unsur hara bagi tanaman yang diperlukan untuk pembentukan dan pertumbuhan vegetative tumbuhan. Fosfor 
dapat mempercepat pertumbuhan akar, mempercepat pemasakan buah, meningkatkan produksi biji. Kekurangan fosfor dapat menyebabkan tanaman menjadi kerdil, perkembangan tidak baik, terlambatnya pemasakan buah dan daun menguning sebelum waktunya(Utomo, 2007).

Bahan lain yang digunakan untuk pembuatan pupuk organik cair ini adalah EM4 dan gula pasir. EM4 adalah sejenis bakteri yang dibuat untuk membantu dalam pembuatan pupuk yang ramah lingkungan berbeda dengan bioaktivator norganik yang berasal dari zat-zat kimia.. Menurut Utomo (2007) Effective mikroorganisme adalah kultur campuran mikroorganisme yang menguntungkan dan memberikan manfaat untuk tanaman serta ramah lingkungan. Mikroorganisme yang ditambahkan pada air rebusan hasil olahan kedelai akan membantu memperbaiki kondisi biologis tanah dan dapat membantu penyerapan unsur hara.

EM4 mengandung mikroorganisme fermentasi dari bakteri asam laktat, bakteri fotosintetik, dan ragi (yeast). Pada proses fermentasi menggunakan EM4 kondisi optimal berlangsung pada kondisi semi anaerob, $\mathrm{pH}$ rendah (3-4), kadar gula tinggi, suhu fermentasi sekitar $40-50^{\circ} \mathrm{C}$. Mikroorganisme yang terdapat dalam EM4 memberikan pengaruh yang baik terhadap kualitas pupuk organik (Yuwono, 2006). Mikroorganisme dalam EM4 dapat meningkatkan penyerapan karbohidrat dan zat hara lainnya (Jumiati, 2009). Selain EM4 bahan utama yang ditambahkan untuk pembuatan pupuk organic dari air rebusan hasil olahan kedelai adalah sukrosa. Sukrosa merupakan suatu karbohidrat sederhana sebagai sumber energy dan nutrisi bagi mikroorganisme saat proses fermentasi (Yuliarti, 2009).

\section{METODOLOGI}

\section{Bahan Penelitian}

Sampel dari penelitian ini merupakan air rebusan olahan kedelai yang diambil dari Kampung Tematik OKE (Olahan Kedelai) Sumurejo Gunungpati, Semarang, EM4, Sukrosa, $\mathrm{H}_{2} \mathrm{SO}_{4}$ pekat $98 \%, \mathrm{NaOH} 40 \%$, asam borat, paraffin cair, indicator Conway, selenium mixture, $\mathrm{HCl} 37 \%$, devarda alloy, larutan standar N, larutan stadar P.

\begin{abstract}
Alat Penelitian
Fermentor, alat gelas, neraca analitik, kertas saring, labu kjeldah, destilator, spektrofotometer UV VIS.

\section{Prosedur Penelitian \\ Pembuatan Pupuk Organik Cair}

Sebanyak $500 \mathrm{ml}$ air rebusan hasil olahan kedelai ditambahkan $15 \mathrm{ml}$ EM4, 10mg sukrosa, diaduk hingga homogen dalam fermentor kemudian ditutup rapat dan diletakkan pada suhu kamar. Hasil fermentasi diambil setiap 4,6,8,10,12,14 hari, kemudian dianalisis kandungan $\mathrm{N}$ dan $\mathrm{P}$. Penelitian dilakukan juga untuk variasi penambahan EM4 sebanyak 5, 10, 15, $20 \mathrm{ml}$ dengan waktu fermentasi 10 hari.
\end{abstract}

\section{Penentuan kandungan $\mathbf{N}$}

Sebanyak 0,25 $\mathrm{g}$ hasil fermentasi dimasukkan dalam labu kjeldah, ditambah 0,25 g selenium mixture dan $3 \mathrm{ml} \mathrm{H}_{2} \mathrm{SO}_{4}$. Destruksi hingga suhu $150 \mathrm{oC}$ dan mencapai maksimum pada suhu $350 \mathrm{oC}$ dan diperoleh cairan jernih. Dinginkan dan encerkan dengan aquades agar tidak terbentuk kristal. Pindah dalam destilator kemudian ditambah aquades hinggah posisi mencapai setengah labu, tambahkan batu didih dan $\mathrm{NaOH} 40 \%$, destilat yang ditampung dalam Erlenmeyer ditambah $10 \mathrm{ml}$ asam borat $1 \%, 3$ tetes indicator Conway kemudian dititrasi dengan $\mathrm{H}_{2} \mathrm{SO}_{4} 0,05 \mathrm{~N}$ hingga ada perubahan warna dari hijau menjadi merah muda (Makiyah, dkk, 2015)

\section{Penentuan Kandungan $P$}

Sebanyak 0,5g larutan hasil fermentasi ke dalam labu kjeldah, ditambah $5 \mathrm{ml} \mathrm{HNO}$, $0,5 \mathrm{ml} \mathrm{HClO} 4$ diaduk merata dan didiamkan selama 12 jam, dipanaskan dari suhu 100 hingga 200 oC. Sebanyak $0,5 \mathrm{ml}$ didinginkan dan diencerkan menggunakan aquades menjadi $50 \mathrm{ml}$, dibiarkan selama 12 jam dan disaring hingga diperoleh ekstrak jernih, kemudian kandungan fosfor dianalisis menggunakan spektrofotometer UV VIS pada panjang gelombang 650-750nm (Makiyah dkk., 2015).

\section{HASIL DAN PEMBAHASAN}

Nitrogen merupakan unsur penting dalam proses pertumbuhan tanaman karena nitrogen sebagai penyusun protein dengan berat molekul tertinggi dan terdiri dari ikatan rantai amino. Nitrogen juga yang berperan untuk warna hijau pada daun (Huda, dkk, 2013). Nitrogen diserap 
dalam bentuk nitrat dan amonium. Pada proses fermentasi air rebusan olahan kedelai menggunakan EM4 menghasilkan nitrogen $(\mathrm{N})$ dengan mekanisme reaksi sebagai berikut :

Protein $\rightarrow \mathrm{TP}+\mathrm{NADP}+\mathrm{NH}_{3}+$ energi

$2 \mathrm{NH}_{3}+3 \mathrm{O}_{2} \rightarrow 2 \mathrm{HNO}_{2}+2 \mathrm{H}_{2} \mathrm{O}+$ energi (2)

$2 \mathrm{HNO}_{2}+2 \mathrm{O}_{2} \rightarrow 2 \mathrm{HNO}_{3}+2 \mathrm{H}_{2} \mathrm{O}+$ energi (3)

Mekanisme reaksi untuk menghasilkan Fosfor sebagai berikut :

ATP + Glukosa $\rightarrow$ ADP + glukosa 6 fosfat (4)

Glukosa 6 fosfat $+\mathrm{H}_{2} \mathrm{O} \rightarrow$ glukosa + fosfat $(5)$

Pada penelitian dilakukan analisis untuk mengetahui kandungan nitrogen dalam pupuk cair dan dapat dilihat pada Gambar 1 .

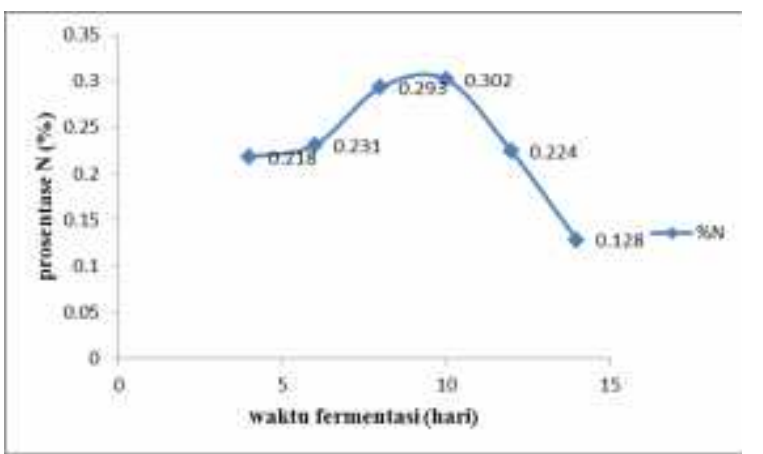

\section{Gambar 1. Grafik Hubungan waktu fermentasi air rebusan olahan kedelai vs prosentase $\mathbf{N}$}

Gambar 1 menunjukkan hubungan antara waktu fermentasi air rebusan hasil olahan kedelai dengan kandungan nitrogen hasil analisis spektrofotometri UV VIS pada panjang gelombang 650-750 nm. Pemilihan panjang gelombang berdasarkan beberapa penelitian yang telah dilakukan sebelumnya tentang pengukuran kandungan nitrogen menggunakan spektrofotometer. Pada Gambar 1 terlihat pada hari ke-4, ke-6, ke-8 bahkan ke-10 kandungan nitrogen mengalami kenaikan dan optimum pada hari ke-10 dengan kandungan nitrogen sebesar $0,302 \%$.

Hal ini dikarenakan penambahan EM4 sebagai bioaktivator mempercepat pemecahan ion-ion pada anode sehingga dihasilkan nitrogen yang berlebih (Endah, dkk, 2008). Penambahan sukrosa juga mengakibatkan pertumbuhan mikroorganisme yang cepat Akan tetapi pada hari ke-12 dan ke-14 mengalami penurunan hingga mencapai $0,128 \%$. Pada hari ke-12 hingga hari ke-14 mikroorganisme akan mencapai kesetimbangan dimana mikroorganisme yang dihasilkan sama dengan mikroorganisme yang mati.

Sehingga aktivitas mikroorganisme untuk pembentukan nitrogen berkurang yang mengakibatkan penyusutan kandungan nitrogen. Hal ini sesuai dengan penelitian yang dilakukan Siburian yang menjelaskan dalm penelitiannya bahwa kadar nitrogen akan menurun seiring bertambahnya hari (Siburian, 2007). Pengukuran kandungan nitrogen pada variasi EM4 yang dapat dilihat pada Gambar 2.

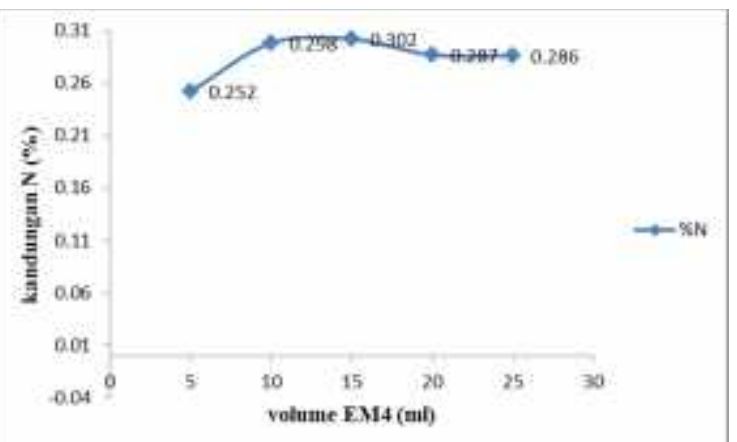

\section{Gambar 2. Grafik Hubunga volume EM4 dengan kandungan $\mathbf{N}$}

Gambar 2 menjelaskan tentang kandungan $\mathrm{N}$ dengan variasi volume EM4 yang ditambahkan. Dari grafik dapat dilihat jika pada penambahan volume 5 dan $10 \mathrm{ml}$ kandungan nitrogen mengalami kenaikan hingga optimum pada penambahan volume $15 \mathrm{ml}$ yang mencapai $0,302 \%$ nitrogen. Pada penambahan volume EM4 sebanyak 15 dan $20 \mathrm{ml}$ kandungan nitrogen mengalami penurunan, hal ini disebabkan pengaruh metabolisme yang mengakibatkan nitrogen yang terbentuk terasimilasi dan volatil karena perubahan menjadi amoniak saat proses denitrifikasi.

Hal ini juga sesuai dengan penelitian yang telah dilakukan Siburian (2008). Alasan lain yang menyebabkan penurunan kandungan nitrogen pada proses pembuatan pupuk organik cair seperti yang dijelaskan oleh Makiyah bahwa tidak terpenuhinya kondisi operasi fermentasi, misal suhu yang rendah atau lebih tinggi dari suhu kamar, $\mathrm{pH}$ yang tidak sesuai akan menyebabkan tumbuhnya bakteri an aerob Thiobacillusdenitrificans dan terjadi proses denitrifikasi, sehingga nitrogen yang terbentuk seyogyanya berada pada fase cair namun dibebaskan ke udara dalam bentuk $\mathrm{N}_{2}$ dengan mekanisme reaksi sebagai berikut (Makiyah, 2013): 
$\mathrm{NO}_{3}{ }^{-}+\left(\mathrm{CH}_{2} \mathrm{O}\right)_{\mathrm{n}}+\mathrm{H}^{+} \rightarrow \mathrm{N}_{2}+\mathrm{CO}_{2}+\mathrm{H}_{2} \mathrm{O}$

Selain nitrogen pada penelitian ini juga dianalisis kandungan fosfor yang dapat dilihat pada Gambar 3.

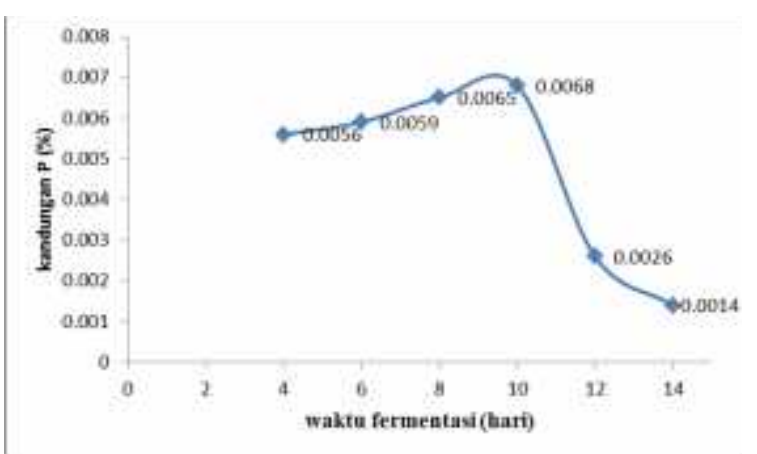

\section{Gambar 3. Grafik Hubungan wakktu fermentasi air rebusan hasil olahan kedelai vs kandungan $P$}

Pada gambar 3 hubungan antara lamanya waktu fermentasi dengan kandungan fosfor mempunyai pola yang sama dengan gambar 1 , dimana grafik yang diperoleh mengalami kenaikan akan tetapi pada suatu ketika akan mengalami penurunan kandungan fosfor. Pada gambar 3 diperoleh kandungan fosfor optimum diperoleh pada waktu fermentasi hari ke-10 sebesar $0,0068 \%$ dan mengalami penurunan hingga $0,0014 \%$ pada hari ke 14 . Pada fase awal jumlah mikroorganisme meningkat sehingga meningkat juga kandungan fosfor.

Kemudian pada hari ke-12 hingga ke-14 terjadi penurunan jumlah mikroorganisme dan banyak mengalami kematian. Karena aktivitas mikroba yang menurun maka kandungan fosfor juga mengalami penurunan. Hal ini sesuai dengan penelitian dari Mashita dimana perubahan kandungan fosfor disebabkan oleh fase mikroorganisme(Makiyah, 2013).

Pola grafik kandungan fosfor dengan penambahan EM4 juga sama dengan gambar 2. Hubungan tersebut dapat dilihat pada gambar 4.

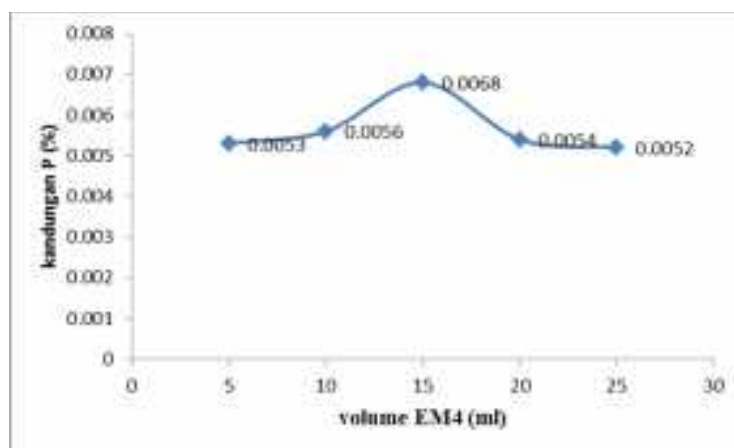

Gambar 4. Grafik Hubungan volume EM4 dengan kandungan $P(\%)$

Pada gambar 4 dapat dilihat bahwa pada penambahan volume dari 5 dan $10 \mathrm{ml}$ akan mengalami kenaikan hingga optimum pada penambahan $15 \mathrm{ml}$ EM4 sebesar $0.0068 \%$ dan mengalami penurunan hingga mencapai 0,0052 pada penambahan $20 \mathrm{ml}$ EM4. Hal ini selain karena fase pertumbuhan mikroorganisme yang mengalami kematian, menurut penelitian yang dilakukan oleh Sani bahwa pengurunan kandungan nitrogen dan fosfor disebabkan oleh masuknya udara ke dalam fermentor saat pengambilan sampel. Karena mikroorganisme dapat beraktivitas dengan baik saat dalam kondisi an aerob (Sani, 2006).

Pendapat lain dari penelitian sebelumnya bahwasanya penurunan kandungan fosfor pada saat proses fermentasi karena sebagian asam organik yang mengandung fosfor bersifat volatil dan menguap ke udara. Berdasarkan hasil penelitian yang telah dilakukan, kandungan nitrogen dan fosfor dari fermentasi air rebusan olahan kedelai menggunakan EM4 yang berada pada jumlah optimum sebesar $0,302 \%$ untuk nitrogen dan $0,0068 \%$ untuk fosfor sesuai dengan baku mutu pupuk organik dan pembentuk tanah menurut Peraturan Menteri Pertanian No.2/Pert. /HK.060/2/2006 yaitu kandungan nitrogen dan fosfor pada pupuk adalah $<5 \%$.

Sedangkan yang dimaksud dengan pembentukan tanah pada Peraturan Menteri Pertanian tersebut adalah bahan-bahan baik sintetis maupun alami baik organik maupun anorganik, padat ataupun cair merupakan bahan yang dapat memperbaiki sifat-sifat tanah (Surawinata, dkk, 2017).

\section{KESIMPULAN}

Pada penelitian ini dapat disimpulkan bahwa air rebusan dari olahan kedelai dapat dimanfaatkan sebagai pupuk organik cair 
dengan kandungan nitrogen dan fosfor yang sesuai dengan baku mutu. Faktor yang mempengaruhi proses pembentukan nitrogen dan fosfor antara lain bioaktivator yaitu effective mikroorganisme yang biasa dikenal dengan EM4 dan lamanya proses fermentasi.

Semakin lama waktu fermentasi dan semakin banyak penambahan bioaktivator kandungan nitrogen dan fosfor akan mengalami penurunan. Hal ini dikarenakan mikroorganisme mempunyai fase pertumbuhan yang bersifat logaritmik. Pada saat seimbang, dimana mikroorganisme yang dihasilkan semakin berkurang, maka mikroorganisme akan mengalami fase kematian sehingga aktivitas pembentukan nitrogen dan fosfor menjadi lambat. Faktor yang lain adalah pembentukan unsur dan senyawa yang bersifat volatil sehingga terjadi penguapan.

\section{DAFTAR PUSTAKA}

Endah, S., Nusa, M., \& Devi, N. C. (2008). Pengaruh agen dekomposter terhadap kualitas hasil pengomposan sampah organik rumah tangga. Sekolah Tinggi dan Teknologi Hayati Institut Teknologi Bandung.

Huda, M. K., Latifah, L., \& Prasetya, A. T. (2013). Pembuatan pupuk organik cair dari urin sapi dengan aditif molasses metode fermentasi. Indonesian Journal of Chemical Science, 2(3).

Jumiati, E. (2009). Pengaruh berbagai konsentrasi em4 pada fermentasi pupuk organik terhadap pertumbuhan dan hasil tanaman bayam merah (amaranthus tricolor 1.) secara hidroponik.

Makiyah, M. (2013). Analisis kadar n, $p$ dan $k$ pada pupuk cair limbah tahu dengan penambahan tanaman matahari meksiko (thitonia diversivolia). Universitas Negeri Semarang,

Makiyah, M., Sunarto, W., \& Prasetya, A. T. (2015). Analisis kadar npk pupuk cair limbah tahu dengan penambahan tanaman thitonia diversivolia. Indonesian Journal of Chemical Science, 4(1).

Mulyaningsih, R., Sunarto, W., \& Prasetya, A. T. (2013). Peningkatan npk pupuk organik cair limbah tahu dengan penambahan tepung tulang ayam. Sainteknol: Jurnal Sains dan Teknologi, 11(1).

Sani, E. Y. (2006). Pengolahan air limbah tahu menggunakan reaktor anaerob bersekat dan aerob. program Pascasarjana Universitas Diponegoro,

Siburian, R. (2007). Pengaruh konsentrasi dan waktu inkubasi em4 terhadap kualitas kimia kompos. Bumi Lestari Journal of Environment, 8(1).

Surawinata, T., Trisnaningsih, U., \& Panuntas, M. M. (2017). Pengaruh konsentrasi pupuk organik cair terhadap pertumbuhan dan hasil pada 3 (tiga) kultivar tanaman kacang hijau (vigna radiata 1.). Agroswagati Jurnal Agronomi, 5(2).

Utomo, A. (2007). Pembuatan kompos dengan limbah organik. Jakarta: $C V$ Sinar Cemerlang Abadi.

Yuliarti, N. (2009). 1001 cara menghasilkan pupuk organik. Andi. Yogyakarta.

Yunizardi, Y. (2017). Pemanfaatan mol (mikroorganisme lokal) dari buahbuahan dan sayuran untuk peningkatan kualitas pupuk organik. Universitas Andalas,

Yuwono, T. (2006). Kecepatan dekomposisi dan kualitas kompos sampah organik. Jurnal inovasi pertanian, 4(2), 116-123. 